\title{
Towards successful implementation of CLIL courses in Russian universities
}

\author{
Aleksei Yu. Alipichev - Alexander A. Galushkin - Svetlana Yu. \\ Dronova - Elena A. Panfilova
}

\section{DOI: 10.18355/XL.2017.10.04.28}

\begin{abstract}
The authors analyze the teaching contents of CLIL courses, evaluate the learning outcomes and professional development opportunities offered by these courses and comment on their implementation in the training process with account of the current practices implemented in European universities. Approaches to CLIL course content planning and design, methods and tools of students' performance assessing, and suggestions on lecturers' retraining are investigated within this paper. Specific features of CLIL courses are revealed by the authors. The research performed allowed elaborating the conceptual scheme of a CLIL course. The authors come to the conclusion that implementation of CLIL in educational process of higher schools is rather perspective area.
\end{abstract}

Key words: content-and-language integrated learning (CLIL), professional foreign language teaching, tertiary professional education, academic mobility.

\section{Introduction}

In recent years, in the framework of international academic mobility programs, training in special (technical, economic, humanitarian) subjects in a foreign language has been actively implemented in European universities. Most lecturers are, as a rule, non-native speakers of foreign languages, and student groups are heterogeneous both ethnically and linguistically. The methodological basis of this training is the concept of Content and Language Integrated Learning (CLIL).

The implementation of this training concept is highly promising not only for students, but also, to an important extent, for educational establishments, first of all, as they intend to achieve the following goals:

- aim to achieve greater international recognition and prestige by issuing double and joint degrees to their graduates (Fürstenberg \& Kletzenbauer, 2015)

- expand the pool of students, including attracting international students and those studying on a contractual basis, which will definitely increase the university incomes

- position themselves in the international arena by creating new opportunities for their students in the global market (Fürstenberg \& Kletzenbauer, 2015)

- enhance educational, economic and cultural partnerships with other countries and contribute to the creation of collaborative networks among universities in academic, professional and research fields (Vázquez \& Ellison, 2013).

Advantages for students are also obvious. These include an in-depth study of the language and special terminology, expansion of their intercultural outlook, broader career opportunities and further training, increased motivation in teaching and research activities, more conscious study of subjects, enriched experience of quasiprofessional learning activity through performing active and interactive tasks and simulating professional functions with the use of a foreign language and, of course, a clearer awareness of their professional and linguistic abilities. "They become more

XLinguae, Volume 10 Issue 4, October 2017, ISSN 1337-8384, eISSN 2453-711X 
confident about the communication skills they are able to develop as they gain confidence, feelings of inhibition and inferiority disappear. By improving their language competence, students gain greater self-awareness of their own capabilities in both the classroom setting and in terms of their future professional development" (Vázquez \& Ellison, 2013).

In a globalized world modern learning environment should be aimed at developing personal intellectual abilities, critical thinking skills, communication skills essential for understanding cultural diversity, cooperation with representatives of various multinational organizations (Kalugina, 2016: 4; Cai et al., 2017; Cao, Kirilova \& Grunis, 2017).

\section{Review of Literature}

The idea for this study developed from research conducted by Ball (2013), Darn (2015); Fürstenberg, Kletzenbauer, (2015), Graddol (2006); Marsh, Mehisto, Wolff, Frigols-Martin (2010), Vázquez, Ellison (2013); Wolff (2012).

The term "CLIL" is generally credited to Professor David Marsh from the University of Jyväskylä, Finland. As he and his colleagues put it: "CLIL is a dualfocused educational approach in which an additional language is used for the learning and teaching of content and language with the objective of promoting both content and language mastery to pre-defined levels" (Marsh et al., 2010).

This concept is based on a dual-focused educational approach and implies teaching of special subjects through the use of a target language pursuing both the knowledge acquisition of the subject matter (professional content) and the development of target language skills to pre-defined levels.

Characteristic features of current European experience are as follows:

- framework base of CLIL teaching is international academic mobility programs

- most lecturers are non-native speakers of foreign languages

- student groups are heterogeneous both ethnically and linguistically.

However, we have to admit that currently the CLIL concept is rather freely interpreted by universities; there is no consent as to the content of subjects taught, as well as the methods of teaching. Lecturers are completely free to choose teaching materials and methods and often they miss the main goal of this "dual subjectlanguage" training and, as a rule, focus their attention solely on the subject content, neglecting many important aspects of language training. Moreover, quite a few lecturers (non-native speakers) also possess formal linguistic qualification. They find it difficult to provide language support to their students and develop their communication skills, as well as transform their materials (in a foreign language) into learning tools for full actualization of their didactic value.

Some universities prefer to invite native speakers, who are specialists in a certain subject area, and may also have a certain experience in teaching language as such, including language for academic purposes. The role of the teacher as a person who provides methodological support for each discipline, organizing in-class work and individual work, taking into account the peculiarities of performance assessment and rating system according to the syllabus is significant (Frolova et al., 2016: 5).

Other higher educational establishments prefer to do their own thing and studies are conducted by "subject" experts who can freely express their course in a foreign language, usually without adequate training in the field of foreign language training. In fact, lecturers do not receive any additional language training and methodological support, the university management believes that independent preparation of scientific papers on their research problems and their presentation at international conferences is sufficient evidence of lecturers' ability and readiness to teach their subject in a foreign language (Golubkova, Masalimova \& Bírová, 2017; Kazakov, Zakirova \& Bírová, 2017; Li, Pyrkova \& Ryabova, 2017). In other words, it 
is assumed that if they are able to use English they are, by definition, already well equipped for teaching in a CLIL situation (Fürstenberg \& Kletzenbauer, 2015). Lecturers have full freedom of choice of teaching materials and teaching methods and often they miss the main goal of this "dual subject-language" preparation and, as a rule, focus their attention solely on subject content, neglecting many important aspects of language training. So they quite often miss the main goal and give lecture-type classes where the focus is on the content but not on English. But content teachers often lack this kind of knowledge about language and therefore tend to ignore the linguistic complexity of the CLIL situation in their lesson planning, which can result in unrealistic lesson plans (e.g. involving too much content for the time available and/or linguistically too complex material) for their CLIL classes (Fürstenberg \& Kletzenbauer, 2015). Thus, the didactic value of the CLIL concept cannot be fully implemented. In addition to the inadequately developed scientific and methodological base, we should also mention the lack of adequate teaching materials, as well as a sound system of professional re-training of academic staff. As Steve Darns stresses there remains a dearth of CLIL-type materials, and a lack of teacher training programmes to prepare both language and subject teachers for CLIL teaching (Darn, 2015).

According to the definition used in foreign scientific sources, especially in works of D. Marsh who is considered to be the founder of the CLIL approach, "CLIL methodology is used to teach certain subjects (or their sections) through a foreign language, and at the same time two goals are achieved: the study of the subject content while simultaneously learning a foreign language (Marsh et al., 2010).

The main characteristic features of the CLIL methodology can be summarized as follows:

- a foreign language is both a learning tool and an object of study

- linguistic and speech content of study (vocabulary, grammar, typical communicative functions, spheres and situations of communication, etc.) is determined by the subject content

- the fluency of professionally focused speech comes to the foreground, so speaking focuses on fluency as accuracy is seen as subordinate (Darn, 2015), and communicatively acceptable speech errors usually do not affect the evaluation of learning outcomes.

Thus, the main advantage of CLIL can be expressed with the help of a figurative expression, actively used in the European methodology: "to kill two birds with one stone" (Ball, 2013).

\section{Materials and Methods}

The main methods used in carrying out this research were:

- literature review on issues concerning the design and implementation of CLIL courses

- surveying European practice of CILI implementation through a series of questionnaires and interviews

- offering trial classes on various aspects of CLIL teaching technique.

\section{Methodology}

The study has been undertaken as part of the methodology of pedagogy, methodology and fundamental pedagogical works considering CLIL as an educational approach, CLIL concept, CLIL teaching and materials, its contribution to educational process.

However, speaking of the design of such courses in Russia (and this is the vital goal at the stage of education internationalization accompanied by the expansion of international ties of higher education establishments in the context of further

XLinguae, Volume 10 Issue 4, October 2017, ISSN 1337-8384, eISSN 2453-711X 
implementation of the Bologna process), we are also faced with our "nationally specific" difficulties. Domestic methodical school has developed sufficient experience in ESP teaching.

Current challenges of CLIL concept implementation in Russian universities include:

- no consent as to the content of the subjects taught, as well as the methods of teaching

- quite a few lecturers (non-native speakers) also possess formal linguistic qualification to provide adequate language support, as well as transform their materials into learning tools for the full actualization of their didactic value

- different levels of FL mastery both of students and their lecturers

As Alekseyeva (2000) claims, domestic FLT experts tend to mix different didactic neoplasms due to a thematic focus in teaching sectoral language (for specific purposes):

- $\quad$ subject matter knowledge - professional realities expressed in a foreign language

- professional skills - communicative abilities and skills, as well as skills in the field of sectoral (professionally oriented) translation.

The purpose of studying a professionally oriented foreign language course is to develop abilities of oral and written communication in a certain field of professional activity, as well as solving various professional tasks by means of a foreign language, including the adequate translation of texts typical for certain spheres and situations of professional communication. Meanwhile, a CLIL course is aimed at mastering professional realities in the framework of taking a course in a foreign language, as a rule, in a multicultural environment within the framework of academic mobility programs (Alipichev, 2011). The translation activities are not supposed here as such because comprehension and systematization of professional realities are carried out only by means of a foreign language.

At the same time, according to foreign researchers, while CLIL courses are an effective tool in the development of language skills, students do not necessarily require a high level of development of these skills for studying a special subject in it. Graddol (2006) argues that the learner is not necessarily expected to have the English proficiency required to cope with the subject before beginning. Learning / acquiring process between mother tongue and foreign language differs at several levels (Birova et al., 2016: 7).

Thus quality design is crucial to effective learning experiences and outcomes (Klimova et al., 2017: 3). Course designers need to pay special attention to the following points:

- methodological requirements for the availability of supply and control of the material assimilation (in the foreign literature the term 'scaffolding' is widely used to denote this process (Hansen-Pauly, 2014; Stevie, 2017)

- the development of innovative techniques (group interactive work, etc.), which would contribute to the formation of professionally important skills (Fürstenberg \& Kletzenbauer, 2015). Interactive methods will allow not only to diversify training, but also to assess the progress of each student, involving them in active work, so that they would fully seek to realize their capacity (Stevie, 2017)

- specially designed training materials should also serve this purpose

- language tools used should clearly reflect the specificity of the lexicalgrammatical constructions of the subject-oriented language

- professional and foreign-language communication skills should be developed in parallel and in an interrelated pattern (Graddol, 2006).

The principal criterion for differentiation between CLIL courses is the lack of communication in the native language. All the training is carried out in a foreign 
language exclusively, and study groups can be heterogeneous, both linguistically and culturally. Therefore, the foreign language chosen for teaching is the only medium of communication between all group members and their course supervisor.

In our opinion, an integral feature of the CLIL course should be the development of academic skills in the field of information retrieval, its processing and presentation of results. However, it should be noted that a special course typically called "English for Academic Purposes" and taught in a number of European universities is most often an elective course, and its content may vary from university to university and do not provide the full scope of the objectives as compared with a course designed within the framework of the CLIL concept. Based on the interviews and questionnaires of a number of lecturers from European universities on optimizing the practice of teaching special subjects in a foreign language, we developed a conceptual outline of the structure and content of a CLIL course.

\section{QUESTIONNAIRE \\ on the design and implementation practice of special subject courses in non-native language (English)}

\section{WHAT}

In your opinion, are there any differences in teaching content between teaching a special (technical, economic, or social) subject in English and in your native language (for example, Russian) -and in task structure (introduction and practical use of terms and expressions, stating cause-and-effect relationships, incomplete data tables etc.)?

What should a typical special subject course design look like? Should it contain only professional topics or some academic, strategic, or informationpresenting skills (any implications of English for academic purposes: patterns and clichés for subject matter discussion and public speaking; commenting on the visuals; summarizing and restructuring textual information etc.)?

Do you add any specific exercises into the task structure (introduction and practical use of terms and expressions in English, stating cause-and-effect relationships, incomplete data tables, case solving tasks etc.)?

\section{HOW}

What are the most efficient study methods, i.e. the ways of interaction between teachers and students, in relation to

- $\quad$ presenting new material;

- discussing the topical issues;

- intended work of the students (information search, project presentation, results discussion?

How do you assess students' performance (i.e. knowledge and skills obtained, including the final assessment)? Do you take into account only the acquisition level of professional matters, or the ability to express the mastery in the particular professional field in a foreign language?

How can students' motivation (both professional and linguistic) be increased with the help of your course in English?

XLinguae, Volume 10 Issue 4, October 2017, ISSN 1337-8384, eISSN 2453-711X 
What kind of specialists - i.e. content teachers or LSP (Language for Specific Purposes) teachers - are supposed to give special subject classes in English?

Are there any requirements for the mastery of English of lecturers engaged in teaching in English?

Is there any need in training and re-training of lecturers engaged in teaching within academic mobility projects?

Do you have any ideas and recommendations on improving the system of teaching in non-native language in your University?

The goal of this paper is to present a conceptual scheme of the structure and content of a CLIL course. We suppose that it should incorporate discursive and linguistic aspects, and training activities should include cognitive (the professional content base in a foreign language), operational (skills of acquiring and developing professionally important information in a foreign language) and communicative-interactive components (finding solutions to problematic situations).

\section{Results and discussion}

A survey was used in order to develop and implement a conceptual scheme of the structure and content of a CLIL course. The questionnaire was distributed among 50 university teachers, involved in teaching ESP and general English; university teachers of different disciplines working at the International Finance Faculty where all the subjects are taught in English. We asked university teachers to reflect their attitude towards the design and implementation practice of special subject courses in non-native language (English). The survey has brought extensive feedback, with the following generalized conclusions.

First, the amount of information offered in English is typically lower as compared with teaching in a native language; moreover, the use of native language allows to explain shades of meanings, in a better and more precise way, while lecturing in English is slightly "simplified".

More than $65 \%$ of respondents are sure that a teacher MUST be prepared with the specialized jargon but FLUENCY, while explaining concepts, is more important because if you have difficulties in explaining the concept, it's much more detrimental than looking for an unknown word in a dictionary.

The acquisition of professional skills is insufficient to be credited for an academic course which should introduce new aspects and perspectives of the matter and a critical reviewing of the state-of-the-art. Any special subject course should NEVER be limited only to professional topics but MUST always include academic skills. Once students have a good grasp of the language, it is much easier for them to develop their strategic/information-presenting skills.

About $75 \%$ of practicing teachers agree that it would be desirable to include academic, information-processing and presenting skills, a lot of attention must be given to Power Point presentations where images and text must be self-explanatory. A mixture of lecturing (presenting new material), in-class discussion of topical materials, use of different forms of reading, links to websites, videos and individual and pair work and interactive group work (e.g. project presentations and essays such as "competitive" journal clubs (teams present the results of one of two conflicting papers followed by general discussion) or case solving exercises (all students join into a team to solve a problem, then organize a final presentation)); on-going formative 
assessment during the week through discussion and various oral and written exercises and summative assessment by means of a group project presentation and a final individual essay. Particular recommendations concern on-going homework correction in class and practice continual trial exam exercises to make students feel more confident. A Student's Electronic Porfolio enables to see students' work in a more complete form at the expense of the use of the text, image, audio and video files; to store, edit and display the students' work. The contents of the folder also are beneficial to the teacher when it comes to overall course grading. Having such a portfolio provides students with the evidence of how well they have performed by the end of semester (Vasbieva \& Klimova, 2015).

As English is currently the standard language for scientists anybody who is willing to face the challenge can be qualified as a CLIL teacher. For such specialist it is extremely important to have sound command of English, and not only academic or special terms. You can realize that the students are following your lessons when they ask you questions in English, or when they laugh when you joke in English.

The university teachers admit the fact that there is definitely need in training and re-training. Although the University provided special courses for the training of the lecturers, there is no formal recognition (in economic or career terms) for the lecturers who improve their skills, so motivation is generally modest. Teachers should have the opportunity (totally founded by the university) to spend 2-3 months per year in an English speaking country to improve their language skills, doing lectures, science or both. Moreover, teaching is rapidly changing due to the new online methods and e-learning platforms which never finish to develop. If a teacher is not trained to use the many tools at hand, he/she may not be aware of the almost unlimited advantages he/she and relative students have. Teachers need to be updated on the new online technologies.

The research performed allowed elaborating the following conceptual scheme of a CLIL course.

Table 1: Conceptual scheme of the structure and content of a CLIL

course

\begin{tabular}{|c|c|c|}
\hline Professional & \multicolumn{2}{|c|}{ Study content structure } \\
\hline Cognitive & Discourse sub-component & Language sub-component \\
\hline (knowledge bank) & $\begin{array}{l}\text { - Lectures (incl. videos) } \\
\text { - Texts for discussion } \\
\text { 1) } \\
\text { 2) } \\
\text { 3) } \\
\ldots \\
\text { n) }\end{array}$ & $\begin{array}{l}\text { - } \quad \text { Glossary } \\
\text { (terminological vocabulary) } \\
\text { - } \quad \text { Grammar references } \\
\text { - } \quad \text { Information search rules } \\
\text { - } \quad \text { Reading strategies } \\
\text { - } \quad \text { Rules for annotating, } \\
\text { abstracting, and reviewing } \\
\text { - Presentation making } \\
\text { rules and clichés } \\
\text { - Scientific etiquette } \\
\text { rules and clichés }\end{array}$ \\
\hline $\begin{array}{c}\text { Operative } \\
\text { component } \\
\\
\text { (conventional } \\
\text { information- } \\
\text { processing tasks) }\end{array}$ & $\begin{array}{ll}\text { - } & \text { explaining } \\
\text { abbreviations and units } \\
\text { of measurements; } \\
\text { - } \quad \text { search, comprehensive } \\
\text { and detail reading; } \\
\text { - } \quad \text { text restoring - blank } \\
\text { filling-in } \quad \text { (sense }\end{array}$ & $\begin{array}{lll}\text { - } & \text { matching terms and } \\
& \text { definitions; } & \\
\text { - } & \text { glossary making; } \\
\text { - } & \text { abbrebiating } & \text { and } \\
\text { conventinonal } & \text { sigh } \\
& \text { reading } \\
\text { - } & \text { grammar exercises } \\
\end{array}$ \\
\hline
\end{tabular}

XLinguae, Volume 10 Issue 4, October 2017, ISSN 1337-8384, eISSN 2453-711X 


\begin{tabular}{|c|c|c|}
\hline & $\begin{array}{l}\text { prediction); } \\
\text { - } \quad \text { panels discussions and } \\
\text { debate panels } \\
\text { - } \quad \text { guessing words from } \\
\text { the context } \\
\text { - } \text { restoring the sequence } \\
\text { of sentences (passages) } \\
\text { - } \text { commenting on visuals } \\
\text { - } \quad \text { true-false statements; } \\
\text { stating cause-and-effect } \\
\text { relationships } \\
\text { (matching); } \\
\text { restoring incomplete } \\
\text { data tables } \\
\text { writing annotations, } \\
\text { abstracts and thematic } \\
\text { reviews; } \\
\text { describing the process, } \\
\text { including digital story } \\
\text { (process description) } \\
\text { making } \\
\text { calculations, } \\
\text { designing and } \\
\text { modeling }\end{array}$ & $\begin{array}{l}\text { (opening the brackets, } \\
\text { restructuring, } \\
\text { simplifying) } \\
\text { Typical grammar } \\
\text { difficulties: } \\
\text { - } \quad \text { Infinitive structures } \\
\text { (for-phrases, Infinitive } \\
\text { of Subsequent Action, } \\
\text { Complex Object, } \\
\text { Complex Subject). } \\
\text { - Participle I, Participle } \\
\text { II and their structures } \\
\text { Absolute and non- } \\
\text { absolute participle } \\
\text { constructions) } \\
\text { The Gerund and its } \\
\text { structures } \\
\text { Substitute words } \\
\text { - Confusable words } \\
\text { - Prepositive attributes } \\
\text { etc. }\end{array}$ \\
\hline $\begin{array}{c}\text { Communicative- } \\
\text { interactive } \\
\text { component } \\
\text { (case solving } \\
\text { problem tasks) }\end{array}$ & \multicolumn{2}{|c|}{$\begin{array}{l}\text { Case-based and role play-based active and interactive } \\
\text { methods implying the use of a FL in a wide range of typical } \\
\text { professional and research based communicative situations } \\
\text { - Study and research motivation and objectives } \\
\text { - International academic mobility projects - searching for } \\
\text { grants and scholarships } \\
\text { - Participation in international scientific conferences - } \\
\text { establishing contacts with organizing committees, } \\
\text { clarifying the conditions of participations etc. } \\
\text { - Planning itineraries of professional trips abroad } \\
\text { - Scientific outcome presentation } \\
\text { - Scientific discussion in different situations (debates, } \\
\text { expositions, interviews by journalists etc.) }\end{array}$} \\
\hline $\begin{array}{l}\text { Typical control } \\
\text { instruments }\end{array}$ & \multicolumn{2}{|c|}{$\begin{array}{l}\text { - } \text { course essays; } \\
-\quad \text { course research project; } \\
-\quad \text { presentation making and digital strory telling related to } \\
\text { issues of professional communication; } \\
-\quad \text { listening comprehension activities based on audio and } \\
\text { video materials; } \\
-\quad \text { case solving tasks (designing algorithms of solving } \\
\text { typical problems in a foreign language); } \\
\text { final exam in the form of an oral conversation. }\end{array}$} \\
\hline
\end{tabular}

But to fully implement all the content elements characteristic of a CLIL course, there should be a certain form of re-training offered to those lecturers engaged in the delivery of CLIL courses in the framework of academic mobility programs.

As a rule, quite a few lecturers (non-native speakers) also have a linguistic qualification, at the same time, every CLIL lecturer is supposed to perfectly know the 
subject taught, as well as should be a proficient speaker of the CLIL language, and also know the methods of teaching, having a good understanding of how languages are learned (Wolff, 2012). As noted above, lecturers of special subjects often unreasonably miss the language aspects, while at the same time fill the teaching content with practical realities, which can also be expressed in a language that is difficult to understand. As Graddol claims, teachers would have to adjust their methodology to ensure that the students understood the content, to think of other means (group work, tasks, etc.) which would result in an increase of the skill-based focus of learning. The educational materials (textbooks) would also have to reflect this approach (Graddol, 2006). Thus, it is extremely important for lecturers to know the methods of teaching and optimally design the content of their courses and specific activities (Ball, 2013).

Especially unusual for many of them is the provision of language support to their students and developing their communication skills, as well as transforming their materials (in a foreign language) into learning tools for the full actualization of their didactic value, in other words, as Fürstenberg and Kletzenbauer put it, to turn their sources into learning resources (Fürstenberg \& Kletzenbauer, 2015). This situation may result in poor planning and frustrating experiences for all class participants: students become demotivated because they cannot complete the tasks successfully due to the lack of adequate language instruction and support, and teachers are dissatisfied with their choice of materials and activities when the results fall short of the expected learning outcomes (Fürstenberg \& Kletzenbauer, 2015). The task of designing an effective training system for such specialists remains to be solved.

We also find it necessary to provide for advanced training of Russian lecturers engaged in delivering courses in a foreign language for international students. The content of the proposed training course includes the following aspects:

1. Academic speaking skills (instructional language and presentation skills);

2. 'Scaffolding' techniques and teaching methods;

3. Intercultural communication awareness module (in academic context).

\section{Conclusion}

To sum it all up, CLIL prospects in Russian universities are rather promising and challenging. The ideas offered in the paper - approaches to a CLIL course content planning and design, methods and tools of students' performance assessing, and suggestions on lecturers' retraining - may provide for the most complete actualization of the didactic value of CLIL courses, that is acquisition of professional realities, the development of skills in searching for and processing of professional information in a foreign language, as well as presenting results and participating in various situations of professional communication. Despite the fact that this technology is close to teaching a professionally oriented language, it has its own specific features that must be taken into account when designing such courses.

\section{Acknowledgements}

1. The research was carried out within the framework of the programme Erasmus Mundus Action 2 Partnerships in the academic mobility project IAMONET$\mathrm{RU}$ and it is based on the materials and teaching experience studied at the University of Udine (Italy), Czech University of Life Sciences Prague (Czech Republic) and the University of Hohenheim (Germany).

2. The work was carried out with the financial support of the Ministry of Education and Science of the Russian Federation under the Peoples' Friendship University of Russia (RUDN University) Program "5-100" among the world's leading research and educational centers for 2016-2020. 


\section{Bibliograpic references}

ALEKSEYEVA, I.S. 2000. Professional training of translators. Manual for oral and written translation for translators and teachers. Saint Petersburg: Institut of foreign languages. 192 p. ISBN 5-93658-001-6.

ALIPICHEV, A.Yu. - KUZNETSOV, A.N. 2011. Designing the teaching content of training sectoral translators: A manual for teachers. Moscow: APKiPPRO. 120 p.

BALL, Ph. 2013. What is CLIL? Available online: http://www.onestopenglish.com/methodology/teaching-articles/teaching-

approaches/what-is-clil/156604.article

BIROVA, J. - KLIMOVA, I.I. - KALUGINA, O. 2016. Some critics on language education assessment. Mathematics Education, vol. 11, n. 7, pp. 2470-2482. ISSN 2468-4945.

BIROVA J. - OCOVAY J. - VASBIEVA, D. G. 2016. Implementation of New Teaching Technologies During The Action Research By Experienced Language Teachers. In: International Electronic Journal of Mathematics Education, vol. 11, n. 8, 3089-3103. ISSN 1306-3030.

CAI, J., - YOUNGBLOOD, V.T. - KHODYREVA, E.A. - KHUZIAKHMETOV, A.N. 2017. Higher Education Curricula Designing on the Basis of the Regional Labour Market Demands. In: EURASIA Journal of Mathematics, Science and Technology Education, vol. 13, n. 7, pp. 2805-2819. ISSN 13058215, 13058223.

CAO, Y. - KIRILOVA, G.I. - GRUNIS, M.L. 2017. Cooperative Research Projects of Master's Students (Education Programs) in the Open Informational Educational Environment. In: EURASIA Journal of Mathematics, Science and Technology Education, vol. 13, n. 7, pp. 2859-2868. ISSN 13058215, 13058223.

DARN S. 2015. CLIL: A Lesson Framework. Available online: https://www.teachingenglish.org.uk/article/clil-a-lesson-framework. Access date: 17.02.2017

FROLOVA, V.B. - KALUGINA O.A. - ARTAMONOVA, L. S. - BOYKOV, A. I. 2016. Studying the Practice of Performance Assessment and Rating System Implementation in Higher Institutions. In: International Electronic Journal of Mathematics Education, vol. 11, n. 5, pp. 1185-1193. ISSN 2468-4945.

FÜRSTENBER, G.U. - KLETZENBAUER, P. 2015. Language-sensitive CLIL teaching in higher education: Approaches to successful lesson planning. ELTWorldOnline.com. Special Issue on CLIL. Available online: http://blog.nus.edu.sg/eltwo/?p=4791. Access date: 17.02.2017

GOLUBKOVA O.N. - MASALIMOVA A.R. - BIROVA J. 2017. The Development of Sociocultural Competence in Future Translators Via the Methodology of CultureOriented Interpretation of English Language Fictional Texts. In: Man in India, vol. 97, n. 14, pp. 73-83. ISSN 00251569.

GRADDOL, D. 2006. English Next. British Council Publications. 128 p.

HANSEN-PAULY, M. A. 2014. Teacher education: Language issues in multilingual educational settings. Council of Europe. Available online: https://www.coe.int/t/dg4/.../Hansen_M-A_rev14022014_EN.docxAccess date: 17.02.2017

KALUGINA, O. 2011. Development of Communicative Competence. Financial Research Institute. Financial Research, n. 4, pp. 179-188. ISSN 2075-1990.

KALUGINA, O.2015. The Formation of Professional and Communicative Competency by Competency-Oriented Exercises (From the Experience of Teaching in a Non-Linguistic Institute of Higher Education). In: Philological Sciences. Issues of Theory and Practice. n. 10-2 (52), pp. 103-106. ISSN 1997-2911.

KALUGINA, O. 2016. The Assessment of Intercultural Communicative Competence. In: Science Review: Humanities Research, n. 9, pp. 55-58. ISSN 2226-0234.

KALUGINA, O.A. 2016. Development of students' professional communicative competence in an economic higher school. In: XLinguae Journal, vol. 9, n. 4, pp: 37 - 
45. ISSN 1337-8393.

KAZAKOV, A.V. - ZAKIROVA, V.G. - BIROVA, J. 2017. Modeling the Process of Forming Social and Cultural Competence among Students of Linguistics Faculty. In: Man In India, vol. 97, n. 14, pp. 291-305. ISSN 00251569.

KLIMOVA I.I. - KALUGINA O.A. - KHALEVINA S. N. - FEDULOVA A. N. TRUBCHENINOVAA. A. 2017. Investigating effective foreign language learning design and the implications for distance learning tools. In: XLinguae., vol. 10, n. 3, pp. 273 - 284. ISSN 1337-8384.

LI, N. - PYRKOVA, K.V. - RYABOVA, T.V. 2017. Teaching Communication Skills and Decision-Making to University Students. In: EURASIA Journal of Mathematics, Science and Technology Education, vol. 13, n. 8, pp. 4715-4723. ISSN $13058215,13058223$.

MARSH, D. - MEHISTO, P. - WOLFF, D. - FRIGOLS-MARTIN, M. 2010. The European framework for CLIL teacher education. Graz: European Centre for Modern Languages, Council of Europe.

PAVON VAZQUEZ, V. - ELLISON, M. 2013. Examining teacher roles and competences in content and language integrated learning (CLIL). In: LINGVARVMARENA, n. 4, pp. 65-78.

STEVIE D. 2017. Teaching Techniques for the CLIL Teacher's Soul. Available online: http://www.fluentu.com/educator/blog/clil-teaching/

VASBIEVA, D.G. - KALUGINA, O.A. 2016. An Analysis of Students' Intercultural Competence Levels in a Non-Linguistic Higher School. In: XLinguae, vol. 9, n. 3, pp.58-69. ISSN 1337-8393.

VASBIEVA, D. G. - KLIMOVA, I. I. 2015. Transformational potential of blended learning to personalize foreign language teaching in a non-linguistic higher school. In: XLinguae, vol. 8, n. 1, pp. 2-10. ISSN 1337-8393.

WOLFF, D. 2012. The European framework of CLIL teacher education. In: Synergies, n. 8, pp.105-116. ISSN 2213-7130.

Words: 5046

Characters: $35356(19,64$ standard page)

Assoc. Prof. Aleksei Yu. Alipichev, PhD (Ed)

Foreign Languages Department

Russian State Agrarian University-Moscow Timiryazev Agricultural Academy

Timiryazevskaya Str., 49

127550 Moscow

Russia

al_new2003@mail.ru

Prof. Alexander A. Galushkin, PhD (Law)

Assoc. Prof. on International Laver

Department of Municipal Law

Peoples' Friendship University of Russia (RUDN University)

Miklukho-Maklaya Str. 6

117198, Moscow

Russia

alexander.galushkin@yandex.ru

Lecturer Svetlana Yu. Dronova

Lecturer Elena A. Panfilova

Department of Foreign Languages

Financial University under the Government of the Russian Federation

XLinguae, Volume 10 Issue 4, October 2017, ISSN 1337-8384, eISSN 2453-711X 
Leningradsky prospect 49

125993 Moscow

Russia

sydronova@fa.ru

eapanfilova@fa.ru 